\title{
IMPLEMENTASI BLENDED LEARNING BY THE CONSTRUCTIVE APPROACH (BLCA) DALAM PEMBELAJARAN INTERAKSI MANUSIA DAN KOMPUTER
}

\author{
Dian Wahyuningsih, C. Asri Budiningsih, \\ Fakultas Ilmu Pendidikan Universitas Negeri Yogyakarta \\ dianwahyuningsih14@yahoo.com
}

\begin{abstract}
Abstrak
Implementasi blended learning by the constructive approach (BLCA) dalam pembelajaran interaksi manusia dan komputer bertujuan untuk meningkatkan pemahaman konsep dan kemandirian belajar dalam pembelajaran interaksi manusia dan komputer (IMK). Penelitian ini merupakan penelitian tindakan yang terdiri dari tiga siklus. Tiap siklus terdiri dari tiga tahap yaitu perencanaan, pelaksanaan dan pengamatan, serta refleksi. Subjek penelitian ini adalah 50 orang mahasiswa Prodi TP FIP UNY. Teknik pengumpulan data yang digunakan yaitu observasi, tes, angket, dan wawancara. Analisis data yang digunakan yaitu deskriptif kuantitatif dan kualitatif. Hasil penelitian menunjukan bahwa,pemahaman konsep dalam pembelajaran IMK meningkat melalui implementasi BLCA dengan rerata nilai tes pada siklus I yaitu 67,56; siklus II menjadi 73,2, dan siklus III menjadi 80,9. Kemandirian belajar dalam pembelajaran IMK meningkat melalui implementasi BLCA, dengan rerata skor angket siklus I yaitu 61,52; siklus II menjadi 64,98; dan siklus III menjadi 68,46. Kesimpulan dari penelitian ini adalah bahwa implementasi BLCAdapat meningkatkan pemahaman konsep dan kemandirian belajar dalam pembelajaran IMK.
\end{abstract}

Kata kunci: blended learning, constructive approach, interaksi manusia dan komputer, pemahaman konsep, kemandirian belajar

\section{THE IMPLEMENTATION OF BLENDED LEARNING BY THE CONSTRUCTIVE APPROACH (BLCA) IN THE COURSE OF HUMAN COMPUTER INTERACTION}

\author{
Dian Wahyuningsih, C. Asri Budiningsih, \\ Fakultas Ilmu Pendidikan Universitas Negeri Yogyakarta \\ dianwahyuningsih14@yahoo.com
}

\begin{abstract}
The implementation of blended learning by the constructive approach (BLCA)In the course of human computer interaction aims to improve understanding of concept and learning autonomy in the course of Human Computer Interaction (HCI). This was an action research study consisting of three cycles. Each cycle consisted of three steps, namely planning, implementation and observation, as well as reflection. The research subjects were 50 students of Educational Technology Department, Faculty of Education, Yogyakarta State University. The data were collected through observations, tests, questionnaires, and interviews. They were analyzed by means of quantitative and qualitative descriptive techniques. The results are as follows. The understanding of concept in the course of HCI was increase through the implementation of BLCA, by the average test scores in cycle I was 67.56;73.2 in cycle II; and 80.9 in the cycle III. Learning autonomy in the course of HCI was increase through the implementation of BLCA, by an average score of the questionnaire in cycle I was 61.52; 64.98 in cycle II, and 68.46 in cycle III. The conclusion of this research was that the implementation of BLCA could improve the understanding of concept and learning autonomy in the course of HCI.
\end{abstract}

Kata kunci: blended learning, constructive approach, human computer interaction, understanding of concepts, learning autonomy 


\section{Pendahuluan}

Belajar adalah kebutuhan setiap individu dalam segala segi kehidupan, baik disadari ataupun tidak. Individu dikatakan telah belajar jika terjadi perubahan pada diri individu tersebut yang diperoleh melalui pengalaman, bukan karena pertumbuhan tubuhnya atau karakteristik individu sejak lahir. Trianto (2011, p.16) menjelaskan bahwa, perubahan yang dimaksud adalah perubahan perilaku tetap berupa pengetahuan, pemahaman, keterampilan, dan kebiasaan yang baru diperoleh individu tersebut. Dalam prakteknya kegiatan belajar terkadang menemui kesulitan dan permasalahan. Berkaitan dengan permasalahan belajar, teknologi pendidikan memiliki peran dalam menyelesaikan masalah belajar yang dihadapai manusia.

AECT (1977, pp.17-18) menjelaskan teknologi pendidikan dalam tiga fungsi yaitu sebagai disiplin ilmu (theoretical construct), bidang garapan (field of endeavor), dan profesi (profession). Teknologi pendidikan sebagai disiplin ilmu yaitu terwujudnya berbagai pola pendidikan dan pembelajaran dengan dikembangkan dan dimanfaatkannya aneka sumber, proses, dan sistem belajar sesuai dengan kondisi dan kebutuhan, menuju terbentuknya masyarakat belajar dan berpengetahuan. Teknologi pendidikan sebagai bidang garapan yaitu penerapan ide-ide dan prinsip-prinsip teoritis untuk memecah kan masalahmasalah aktual di bidang pendidikan dan pembelajaran. Teknologi pendidikan sebagai profesi adalah kelompok khusus praktisi yangt erorganisir, yang memenuhi kriteria tugas dan yang menghubungkan antarbagian teori ke dalam praktek.

Penjelasan di atas mengungkapkan bahwa teknologi pendidikan sebagai suatu disiplin ilmu, bidang garapan, dan profesi berkepentingan pada bidang kajian belajar dan pembelajaran manusia. Hal tersebut seperti ungkapan Yusufhadi Miarso (2007, p.62) bahwa, objek formal teknologi pendidikan adalah "belajar" pada manusia, baik sebagai pribadi maupun yang tergabung dalam organisasi. Lebih lanjut
Yusufhadi Miarso (2007, p.16) menjelaskan kompetensi yang harus dikuasi oleh lulusan teknologi pendidikan diantaranya, yaitu: mampu memahami landasan teori dan aplikasi teknologi pendidikan, merancang pola pembelajaran, memproduksi media pendidikan, mengevaluasi program dan produk pembelajaran, mengelola media dan sarana belajar, memanfaatkan media pendidikan dan teknik pembelajaran, menyebarkan informasi dan produk teknologi pendidikan, serta mengelola lembaga sumber belajar.

Permasalahan belajar selalu ada di setiap zaman. Semakin berkembang ilmu pengetahuan dan teknologi semakin berkembang pula permasalahan belajar manusia. Dewasa ini teknologi komputer dan internet berkembang pesat ke segala bidang termasuk pendidikan. Secara praktis masalah belajar yang dihadapai manusia saat ini muncul dan berkembang dengan keberadaan teknologi tersebut. Hal ini mendorong institusi penyelenggara disiplin ilmu Teknologi Pendidikan (TP) salah satunya Fakultas Ilmu Pendidikan (FIP) Universitas Negeri Yogyakarta (UNY), untuk membekali mahasiswanya dengan mata kuliah yang sesuai dengan perkembangan teknologi tersebut. Mata kuliah yang dimaksud diantaranya adalah Interaksi Manusia dan Komputer (IMK).

Mata kuliah IMK dituangkan dalam kurikulum Program Studi Teknologi Pendidikan guna menunjang kompetensi yang harus dikuasai oleh mahasiswanya. Mata kuliah ini bersifat teoritis, sehingga lebih banyak mengajarkan teori daripada praktek. Hal tersebut diketahui dari proporsi mata kuliah IMK yaitu 3 SKS, 2 SKS untuk teori dan 1 SKS untuk praktek (FIP UNY, 2009, p.87). Dalam mata kuliah ini, praktek memiliki porsi lebih kecil dari teori karena difungsikan sebagai penunjang tercapainya pemahaman teori yang diajarkan.

Tujuan mata kuliah IMK pada Prodi FIP TP yaitu mahasiswa mampu merancang, mengimplementasikan, dan mengevaluasi sistem komputasi interaktif. Agar tujuan mata kuliah tersebut tercapai strategi yang digunakan yaitu pengajaran teori 
dilakukan beriringan dengan praktek. Praktek dalam hal ini tidak hanya diartikan sebagai praktek secara fisik dalam mengoperasikan benda atau sistem saja, tetapi praktek diartikan sebagai penerapan pengetahuan dalam memecahkan permasalahan (Seels \& Richey, 1994, p.10). Oleh karena itu, dalam implementasinya teori dan praktek harus beriringan dan sejalan tidak boleh terpisahkan.

Dengan mempelajari teori yang diiringi dengan praktek, mahasiswa menjadi paham akan teori yang diajarkan dan praktek akan berjalan lancar dan terarah. Seels \& Richey (1994, p.10) mengungkapkan, teori terdiri dari konsep, bangunan (konstruk), prinsip, dan proposisi yang memberi sumbangan terhadap khasanah pengetahuan. Pemahaman teori berupa konsep merupakan dasar dari pemahaman teori lainnya, sehingga pemahaman konsep harus dikuasai terlebih dahulu oleh mahasiswa. Agar mahasiswa mampu memahami konsep, pelaksanaan praktek diupayakan diterapkan sesuai konteks materi dari konsep yang dipelajari.

Pada kenyataannya mengajarkan teori dan praktek secara beriringan bukan pekerjaan yang mudah, baik dosen maupun mahasiswa harus aktif. Dosen aktif merancang kegiatan belajar yang sesuai konteks materi dan aktif membimbing mahasiswa, sedangkan mahasiswa aktif menemukan sendiri pemahaman konsepnya. Oleh karena itu, dosen harus lebih kreatif dalam mengajar dan mahasiswa harus memiliki kemandirian belajar yang tinggi. Memiliki kemandian belajar merupakan salah satu kunci sukses belajar di perguruan tinggi (Eti Nurhayati, 2011, p.52). Jika mahasiswa tidak memiliki kemandirian belajar yang tinggi akan sulit melakukan upaya menemukan sendiri pemahaman konsepnya.

Berdasarkan hasil wawancara terhadap dosen pengampu mata kuliah IMK Prodi TP FIP UNY diperoleh informasi mengenai pelaksanaan pembelajaran pada mata kuliah IMK. Dalam mengampu mata kuliah IMK selama ini, dosen mengajarkan teori secara terpisah dari praktek. Teori diajarkan terlebih dahulu di pertemuan awal hingga pertengahan kuliah kemudian praktek pada pertemuan pertengahan hingga akhir.

Pada pelaksanaannya praktek dianggap lebih penting untuk dikuasai terlebih dahulu dibandingkan dengan teori, sehingga dosen mengurangi porsi pengajaran teori dan menambah porsi pengajaran praktek. Hal tersebut berlawanan dengan pelaksanaan pembelajaran dalam disiplin ilmu TP, di mana teori dan praktek seharusnya dilakukan beriringan secara sistematik, sinergis, dan sistemik. Dengan pelaksanaan pembelajaran tersebut, mahasiswa menjadi tidak memahami konsep IMK sehingga praktek yang dilakukan menjadi tidak terarah dan kurang maksimal.

Dosen telah berupaya mengatasi hal tersebut dengan melakukan pembelajaran online untuk mengajarkan teori. Pembelajaran online dilakukan melalui blog, e-mail, dan jejaring sosial. Namun, upaya tersebut belum berhasil karena pembelajaran online yang diterapkan tidak dapat memfasilitasi mahasiswa dalam belajar dan cenderung bersifat satu arah sehingga hasilnya tidak efektif. Penggunaan jejaring sosial juga tidak membantu kelancaran kegiatan pembelajaran, karena jejaring sosial menjadikan mahasiswa tidak fokus belajar.

Agar lebih jelas mengetahui permasalahan mengenai pemahaman konsep pada mahasiswa, peneliti melakukan tes pemahaman konsep pada mahasiswa yang telah memperoleh mata kuliah IMK. Hasil tes pemahaman konsep terhadap 35 orang mahasiswa menunjukan bahwa, persentase mahasiswa yang memperoleh nilai tuntas dalam mata kuliah IMK sebesar 17,14\%, dengan rata-rata nilai 52,34. Kriteria ketuntasan minimal dalam mata kuliah IMK yang ditetapkan oleh dosen adalah $\geq$ 70,00 atau setara dengan nilai B (UNY, 2011: 13).Dari hasil tes tersebut jelas bahwa pemahaman konsep IMK mahasiswa rendah.

Berdasarkan hasil wawancara terhadap mahasiswa Prodi TP FIP UNY yang 
telah menempuh mata kuliah IMK diperoleh informasi bahwa, mahasiswa mengalami kesulitan dalam mengaplikasikan mata kuliah IMK dalam kehidupan nyata. Hal tersebut terjadi sebagai akibat dari tidak dipahaminya konsep IMK secara matang, karena model dan pendekatan pembelajaran yang diimplementasikan kurang tepat. Dalam perkuliahan, dosen masih mendominasi proses pembelajaran. Hal tersebut menjadikan mahasiswa bersikap pasif dan mengandalkan dosen sebagai satu-satunya sumber belajar. Mahasiswa menjadi kurang mandiri untuk mencari sumber belajar lain yang relevan dengan materi yang diajarkan, serta malas dan kurang bertanggung jawab dalam menyelesaikan tugas belajarnya.

Pengajaran teori disajikan melalui presentasi oleh dosen semata. Hal tersebut membuat mahasiswa tidak memiliki inisiatif dalam menanggapi materi pembelajaran dari dosen, sehingga pembelajaran lebih banyak berpusat pada dosen (teacher centered learning) dibanding berpusat pada mahasiswa (student centered learning). Kecenderungan pelaksanaan proses pembelajaran dengan model pembelajaran tersebut menjadikan mahasiswa tidak dapat menghubungkan keterkaitan antara teori dan praktek. Hal tersebut mengakibatkan mahasiswa tidak mampu mencapai kompetensi dalam mata kuliah IMK karena rancang, implementasi, dan evaluasi sistem komputasi interaktif tidak sesuai antara teori dengan prakteknya.

Dari uraian di atas dapat disimpulkan bahwa tujuan pembelajaran pada mata kuliah IMK belum tercapai. Hal tersebut disebabkan karena pemahaman konsep IMK dan kemandirian belajar mahasiswa masih rendah. Permasalahan tersebut berakar pada kurang tepatnya model dan pendekatan pembelajaran yang diterapkan oleh dosen. Joyce, Weil, \& Calhoun (2011, p.7) menjelaskan model pembelajaran sebagai seperangkat cara agar peserta didik mampu meningkatkan kapabilitasnya untuk dapat belajar lebih mudah dan lebih efektif pada masa yang akan datang, baik karena pengetahuan dan skill yang diper- oleh maupun karena penguasaan tentang proses belajar yang lebih baik. Model pembelajaran merupakan kunci peningkatan kualitas pembelajaran. Desain model pembelajaran harus sesuai dengan kompetensi yang ingin dicapai. Selain itu, desain modelpembelajaran juga harus memperhatikan karakteristik peserta didik, karakteristik materi dan sumber daya yang dimiliki.

Untuk mengatasi permasalahan tersebut, perlu kiranya diimplementasikan model pembelajaran yang sesuai dengan karakteristik mata kuliah IMK dan mahasiswa TP FIP UNY, serta dilakukan dengan pendekatan pembelajaran yang berpusat pada mahasiswa. Model dan pendekatan pembelajaran tersebut adalah blended learning by the constructive approach (BLCA). Blended learning oleh Cheung \& Hew (2011, p.1) diartikan sebagai kombinasi antara pembelajaran tatap muka (face to face learning) dengan pembelajaran online (online learning). Uwes A. Chaeruman (2012) menjelaskan blended learning sebagai pembelajaran yang mengkombinasikan seting pembelajaran synchronous dan asynchronous secara tepat guna untuk mencapai tujuan pembelajaran.Krause dalam Bath \& Bourke (2010: 1) menjelaskan

"blended learningrealised in teaching and learning environments wherethere is an effective integration of different modes of delivery, models ofteaching and styles of learning as a result of adopting a strategic andsystematic approach to the use of technology combined with the best featuresof face to face interaction".

Constructive approach (pendekatan konstruktif) diartikan sebagai usaha mengarahkan peserta didik untuk membentuk pengetahuannya sendiri dengan cara memberikan makna kepada pengalamannya melalui asimilasi dan akomodasi yang menuju pada pemutakhiran struktur kognitifnya (Asri Budiningsih, 2005, p.58).

Keunggulan BLCA yaitu adanya perpaduan yang khas antara blended learning dengan contructive approach (pendekat- 
an konstruktif). Nel (2005, pp.18-19) mengemukakan bahwa, blended Learning memiliki keunggulan diantaranya pendekatan belajar yang beragam, lebih mudah dalam mengakses pengetahuan, adanya interaksi sosial, dan memudahkan dalam melakukan revisi. Keunggulancontructive approach (pendekatan konstruktif) diantara dapat melatih kemandirian belajar mahasiswa dalam membangun konsep berdasarkan pemikiran sendiri (Arends, 2008, p.112).

BLCA diharapkan mampu mengatasi pemasalahan pembelajaran pada mata kuliah IMK Prodi TP FIP UNY, dikarenakan BLCA mampu mengakomodasi karakteristik mata kuliah IMK dan mahasiswa TP FIP UNY, serta pendekatan pembelajarannya berpusat pada mahasiswa. Berdasarkan uraian tersebut, peneliti menganggap penting melakukan penelitian dengan judul: implementasi blended learning by the constructive approachuntuk meningkatkan pemahaman konsep dan kemandirian belajarmahasiswa dalam Mata kuliahInteraksi Manusia dan Komputer Prodi TP FIP UNY.

\section{Metode Penelitian}

Jenis Penelitian

Penelitian ini merupakan penelitian tindakan (action research) yang mengacu pada desain penelitian spiral dari Kemmis \& Mc Taggart (1990, p.11). Model spiral tersebut berupa tiga langkah kesatuan berulang yaitu plan (perencanaan), act (pelaksanaan tindakan) dan observe (observasi), serta reflect (refleksi). Penelitian ini dilakukan secara kolaboratif (collaborative action research), di mana dosen pengampu mata kuliah IMK Prodi TP FIP UNY bekerja sama dengan peneliti sejawat dengan jalan mengidentifikasi masalah pembelajaran yang muncul yaitu kurang tepatnya model pembelajaran yang diterapkan dalam mata kuliah IMK menyebabkan pemahaman konsep dan kemandirian belajar mahasiswa Prodi TP FIP UNY menjadi rendah.
Dilanjutkan dengan merancang tindakan untuk mengatasi permasalahan tersebut, melaksanakan tindakan yang dirancang, serta mengobservasi dan merefleksikan tindakan secara kolaboratif dan partisipatif. Hal tersebut dilakukan dengan tujuan untuk mengatasi masalah pembelajaran dan meningkatkan mutu pembelajaran khususnya untuk meningkatkan pemahaman konsep dan kemandirian belajar mahasiswa Prodi TP UNY dalam mata kuliah IMK.

\section{Waktu dan Tempat Penelitian}

Penelitian ini dilakukan ketika mata kuliah Interaksi Manusia dan Komputer mahasiswa Prodi TP FIP UNY berlangsung baik secara synchronous dan asynchronous. Penelitian ini dilaksanakan pada bulan Februari-April 2013, yaitu ketika mahasiswa konsentrasi menempuh mata kuliah Interaksi Manusia dan Komputer (IMK) pada tahun ajaran 2012/2013. Penelitian dilakukan secara bertahap mulai dari siklus pertama sampai siklus yang menunjukan keberhasilan implementasi BLCA, serta adanya peningkatan pemahaman konsep dan kemandirian belajar mahasiswa dalam mata kuliah IMK Prodi TP UNY sesuai kriteria keberhasilan yang ditetapkan.

\section{Subjek Penelitian}

Subjek dalam penelitian ini adalah mahasiswa Prodi TP FIP UNY konsentrasi Teknologi Informasi dan Komunikasi Pendidikan yang menempuh mata kuliah IMK pada semester IV. Subjek pada penelitian ini berjumlah 50 orang dan diambil dengan teknik purposive.

\section{Prosedur}

Setiap siklus dalam penelitian tindakan ini dilakukan dalam tiga kali tatap muka dan tiga minggu kegiatan pembelajaran online. Kegiatan yang dilakukan pada tahap perencanaan yaitu membuat skenario pembelajaran yang mengacu model BLCA. Skenario pembelajaran disusun dengan pertimbangan dosen pengampu 
mata kuliah IMK Prodi TP UNY. Skenario pembelajaran tersebut berguna sebagai pedoman dosen dalam melaksanakan kegiatan pembelajaran. Menyusun dan menyiapkan instrumen penelitian yang meliputi lembar observasi, tes, angket, dan pedoman wawancara. Mempersiapkan sarana prasarana yang digunakan dalam pembelajaran, meliputi: mengecek keberfungsian komputer dalam laboratorium komputer yang digunakan sebagai ruang kelas mata kuliah IMK bagi mahasiswa Prodi TP FIP UNY, membuat course IMK dalam Besmart UNY, mempersiapkan bahan dan tugas belajar dalam format fisik atau tercetak dan digital, serta mengunggah bahan dan tugas belajar tersebut dalam e-learning yang telah dibuat.

Kegiatan yang dilakukan pada tahap pelaksanaan dan pengamatan yaitu melaksanakan tindakan berupa lima langkah pembelajaran BLCA. Tindakan dilakukan oleh dosen dengan menggunakan skenario pembelajaran yang telah dibuat peneliti sebagai panduan pelaksanaan tindakan, sedangkan peneliti bertindak sebagai pengamat. Dalam pelaksanaan tindakan di lapangan skenario pembelajarn yang telah disusun menyesuaikan taktik/ gaya dosen saat mengajar, sehingga pelaksanaan pembelajaran terkesan tidak dibuat-buat.

Pengamatan dilaksanakan selama proses pembelajaran belarlangsung baik secara synchronous dan asynchronous. Pengamatan dilakukan oleh peneliti menggunakan lembar observasi yang telah disusun, untuk melihat langkah implementasi BLCA serta peningkatan pemahaman konsep dan kemandirian belajar mahasiswa Prodi TP FIP UNY dalam pembelajaran IMK. Setelah itu, memberikan tes pemahaman konsep dan angket kemandirian belajar kepada mahasiswa untuk mengetahui pemahaman konsep dan kemandirian belajar yang telah diperoleh, kemudian dilakukan wawancara kepada mahasiswa mengenai pelaksanaan pembelajaran dengan impelementasi BLCA.

Kegiatan yang dilakukan pada tahap refleksi yaitu Pada tahap ini dilakukan diskusi, perenungan, dan pemikiran se- bagai upaya evaluasi yang dilakukan terkait penelitian yang telah dilaksanakan. Refleksi dilakukan secara kolaboratif antara peneliti dan dosen pengampu mata kuliah IMK Prodi TP FIP UNY setelah adanya tindakan dan hasil pengamatan. Berdasarkan refleksi tersebut, tindakan yang telah mencapai keberhasilan tetap dilanjutkan, sedangkan tindakan yang belum mencapai keberhasilan dilakukan perbaikan tindakan pada siklus selanjutnya.

\section{Teknik dan IntrumenPengumpulan Data}

Untuk mendapatkan data mengenai Implementasi BLCA untuk meningkatkan pemahaman konsep dan kemandirian belajarmahasiswa dalam Pembelajaran teknik pengumpulan data yang digunakan meliputi observasi, tes, angket, dan wawancara.

Teknik observasi yang digunakan dalam penelitian ini adalah observasi terfokus dan terstruktur. Teknik observasi terfokus digunakan untuk mengamati fokuspermasalahan yaitu implementasi BLCA dalam pembelajaran IMK. Teknik observasi terstruktur digunakan peneliti untuk menghindari subyektifitas peneliti. Observasi terstruktur ditandai dengan perekaman data yang relatif sederhana, dengan telah disediakan format rekaman yang rinci sehingga peneliti tinggal membubuhkan tanda cacah (tallies) agar gejala yang diamati terpetakan secara rapi (Wijaya \& Dedi, 2010, p.66).Instrumen yang digunakan adalah lembar observasi.

Pada penelitian ini tes digunakan untuk memperoleh data mengenai pemahaman konsep IMK mahasiswa dalam mata kuliah tersebut setelah dikenai tindakan berupa implementasi BLCA. Jenis tes yang digunakan dalam penelitian ini adalah tes tertulis berbentuk pilihan ganda. Instrumen yang digunakan adalah lembar tes pilihan ganda. Kuesioner yang digunakan dalam penelitian ini adalah kuesioner tertutup. Instrumen yang digunakan adalah lembar angket.

Wawancara digunakan untuk memperoleh informasi yang lebih terperinci 
dari mahasiswa tentang proses pembelajaran IMK dengan implementasi BLCA yang meliputi materi, lingkungan, dosen, sumber belajar, dan model pembelajaran untuk melengkapi data hasil observasi. Bentuk wawancara yang digunakan adalah wawancara mendalamsetengah terstruktur, yaitu wawancara yang sudah dipersiapkan dahulu daftar pertanyaannya namun tetap memberi keleluasaan informanuntuk menerangkan jawabannya.Instrumen yang digunakan adalah pedoman wawancara.

\section{Teknik Analisis Data}

Teknik analisis data dalam penelitian ini adalah analisis deskriptif. Ada dua jenis data dalampenelitian tindakan ini yaitu data kualitatif dan data kuantitatif. Data kualitatif yakni berupa informasi hasil wawancara dan keterangan observasi berbentuk kalimat yangmemberikan gambaran tentang kegiatan dan ekspresi mahasiswa berkaitan dengan tingkatpemahaman konsep IMK dan gejala peningkatan kemandirian belajar. Analisis data kualitatif dilakukan dengan model Miles dan Huberman yaitu melalui langkah reduksi data, display/penyajiandata, dan menarik kesimpulan atau verifikasi (Iskandar, 2008, p.222).

Data kuantitatif yaitu berupa data hasil ceklis observasi pelaksanaan pembelajaran dengan model BLCA, observasi pemahaman konsep IMK, dan observasi kemandirian belajar mahasiswa, tes pemahaman konsep IMK, dan angket kemandirian belajar mahasiswa yang dianalisis menggunakan statistik deskriptif dengan penyajian tabel berdasarkan kategori dan presentase. Penentuan kategori mengacu pada perhitungan menurut Eko Putro Widoyoko (2012, p.110).

Interval $=\underline{\text { banyak skor tertinggi }- \text { banyak skor terendah }}$ banyak kriteria

Setelah jarak interval diketahui, kategori dalam setiap indikator dapat diketahui. Setelah kategori diketahui, kemudian menentukan persentase jumlah mahasiswa yang mencapai kriteria keberhasilan dengan menggunakan rumus sebagai berikut.
Persentase $=$ jumlah skor yang diperoleh $\times 100 \%$ jumlah skor maksimal

Data yang dikumpulkan melalui tes yaitu pemahaman konsep IMK dihitung jumlah skor perolehan masing-masing mahasiswa, dan dari skor ditentukan nilai mahasiswa dengan mengadaptasi perhitungan menurut Djemari Mardapi (2008, p.61) sebagai berikut.

$$
\text { nilai }=\frac{\text { jumlah skor yang diperoleh }}{\text { jumlah skor maksimal }} \times 100
$$

Setelah diketahui masing-masing nilai mahasiswa, data dianalisis untuk mencari nilai rata-rata kelas dengan menggunakan rumus dalam Sugiyono (2012, p.49) sebagai berikut:

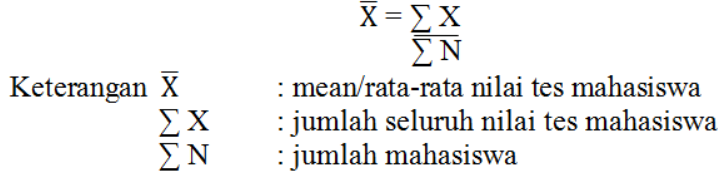

Variabel pemahaman konsep dan kemandirian belajar berdasarkan observasi keduanya memiliki 12 butir pernyataan, sehingga skor total bergerang dari skor terendah $12(12 \times 1)$ sampai dengan tertinggi $48(12 \times 4)$. Data hasil observasi dianalisis dengan cara menentukan skor yang didapat dari masing-masing siklus. Berikut disajikan tabel kualifikasi perolehan skor observasi pemahaman konsep dan kemandirian belajar.

Tabel 1. Kualifikasi Perolehan Skor

Pemahaman Konsep dan Kemandirian Belajar Berdasarkan Observasi

\begin{tabular}{cc}
\hline Jumlah Skor Perolehan & Kategori \\
\hline $39 \leq \mathrm{x} \leq 48$ & Sangat Tinggi \\
\hline $30 \leq \mathrm{x} \leq 38$ & Tinggi \\
\hline $21 \leq \mathrm{x} \leq 29$ & Rendah \\
\hline $12 \leq \mathrm{x} \leq 20$ & Sangat rendah \\
\hline
\end{tabular}

Terdapat 22 butir pernyataan dalam angket kemandirian belajar, sehingga skor total bergerang dari skor terendah 22 $(22 \times 1)$ sampai dengan tertinggi $88(22 \times 4)$. Data hasil angket dianalisis dengan cara menentukan skor yang didapat dari ma- 
sing-masing siklus. Setelah kategori diketahui, kemudian ditentukan persentasenya. Berikut disajikan tabel kualifikasi perolehan skor angket kemandirian belajar mahasiswa mengacu pada perhitungan menurut Eko Putro Widoyoko (2012, p.110).

Tabel 2. Kualifikasi Skor Angket Kemandirian Belajar

\begin{tabular}{lc}
\hline Jumlah Skor Perolehan & Kategori \\
\hline $71,5 \leq x \leq 88$ & Sangat tinggi \\
\hline $55 \leq x \leq 71,4$ & Tinggi \\
\hline $38,5 \leq x \leq 54,9$ & Rendah \\
\hline $22 \leq x \leq 38,4$ & Sangat rendah \\
\hline
\end{tabular}

\section{Hasil Penelitian dan Pembahasan}

Peningkatan Pemahaman Konsep IMK

Hasil penelitian menunjukan bahwa pemahaman konsep IMK mengalami peningkatan dengan implementasi BLCA. Pada kondisi awal nilai rata-rata tes pemahaman konsep mahasiswa yaitu 52,34, sedangkan mahasiswa yang mencapai ketuntasan belajar atau mendapat nilai $>70,00$ berjumlah 6 orang dengan persentase 17,14\%. Hal tersebut menunjukan bahwa pemahaman konsep mahasiswa Prodi TP FIP UNY dalam pembelajaran IMK masih rendah.

Pemahaman konsep IMK mengalami peningkatan melalui implementasi BLCA, dengan rata-rata nilai tes mahasiswa pada siklus I yaitu 67,56 yang belum mencapai kriteria keberhasilan. Pada siklus II dan III terjadi peningkatan dari siklus I dan telah mencapai kriteria keberhasilan menjadi 73,2 pada siklus II dan 80,9 pada siklus III. Jumlah mahasiswa yang mencapai ketuntasan belajar pada siklus I yaitu $52 \%$, naik pada siklus II menjadi $70 \%$, dan naik pada siklus III menjadi $84 \%$.

Berdasarkan hasil observasi, Pemahaman konsep IMK mengalami peningkatan dengan skor pada siklus I yaitu 23 (rendah), naik pada siklus II menjadi 31 (tinggi), dan naik pada siklus III menjadi 37 (tinggi). Hasil tes pemahaman konsep IMK siklus I hingga siklus III dapat dilihat dalam lampiran 24 halaman 314. Peningkatan pemahaman konsep IMK dengan implementasi BLCA dari siklus I hingga siklus III, dapat dilihat pada tabel dan gambar sebagai berikut.

Tabel 3. Nilai Tes Pemahaman Konsep IMK

\begin{tabular}{lccc}
\hline \multicolumn{1}{c}{ Keterangan } & $\begin{array}{c}\text { Siklus } \\
\text { I }\end{array}$ & $\begin{array}{c}\text { Siklus } \\
\text { II }\end{array}$ & $\begin{array}{c}\text { Siklus } \\
\text { III }\end{array}$ \\
\hline Nilai tertinggi & 84 & 96 & 94 \\
Nilai terendah & 44 & 39 & 59 \\
\hline Rata-rata nilai & 67,56 & 73,2 & 80,9 \\
\hline $\begin{array}{l}\text { Jumlah mahasiswa } \\
\text { dengan nilai }>70,00\end{array}$ & 26 & 35 & 42 \\
\hline $\begin{array}{l}\text { Persentase mahasiswa } \\
\text { yang mencapai } \\
\text { ketuntasan belajar }\end{array}$ & $52 \%$ & $70 \%$ & $84 \%$ \\
\hline
\end{tabular}

Gambarkan 1 menunjukkan peningkatan pemahaman konsep IMK melalui implementasi BLCA berdasarkan observasi.

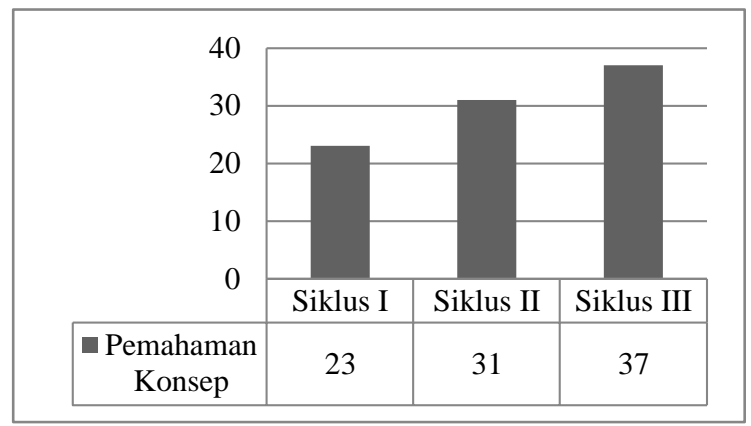

Gambar 1. Peningkatan Pemahaman Konsep IMK Berdasarkan Observasi

Berdasarkan observasi, peningkatan pemahaman konsep IMK dari siklus I hingga siklus III terjadi karena materi disajikan dari hal yang bersifat umum ke hal yang lebih khusus. Gaya dosen dalam mengajar dengan menghubungkan pengetahuan lama dengan pengetahuan baru mahasiswa, serta memberikan penekanan ritmis, menggunakan gerak isyarat, dan ilustrasi pada saat menjelaskan materi memberi kemudahan bagi mahasiswa dalam menyusun skema mengenai konsepkonsep dalam IMK.

Hal tersebut senada dengan penjelasan dari Gagne, et al (2005: 118) yaitu "in approaching learning from newly presented instruction, learners come to the task with 
various schemas already in their memories." Melalui kegiatan tersebut kemampuan interpreting, exemplifying, dan classifying dalam konsep-konsep IMK menajdi meningkat. Kegiatan belajar ini dilakukan dengan live synchronous melalui kegiatan orientasi materi di kelas dan autonomous asynchronous dengan mengekplorasi materi pembelajaran yang relevan dengan materi dalam course IMK Besmart UNY.

Berdasarkan wawancara, melalui strategi PBL memberikan kemudahan mahasiswa dalam membangun pemahaman konsepnya. Dalam kegiatan investigasi mahasiswa melakukan kegiatan mendefinisikan masalah, menemukan penyebab terjadinya masalah, dan mencari solusi penyelesaian masalah. Kegiatan tersebut merupakan aktualisasi penerapan teori yang beriringan dengan praktek, sehingga mahasiswa langsung dapat menghubungkan antara materi yang dipelajari dengan konteks dalam kehidupan nyata. Hal tersebut sesuai dengan penjelasan Littlejohn \& Pegler (2007: 134-135) yaitu:

PBL usually begins with an open-ended problem around which student groups organize their studies. These activities are reflecting and constructive, raising students' awareness and skills in solving complex problem. The strength of this strategy is not simply the access to high-quality learning resources, but that it encourages students to reflect upon their learning at different stages.

Kegiatan tersebut dilakukan dengan melakukan aktivitas collaborative $\mathcal{E}$ autonomous asynchronous dalam pembelajaran online dan live synchronous pada kegiatan tatap muka.

Dengan menggunakan PBL tersebut proses pembelajaran menjadi berpusat kepada mahasiswa, sehingga proses pembelajaran IMK menjadi meningkat. Hal tersebut diketahui melalui aktivitas mahasiswa dalam melakukan kegiatan organisasi dan investigasi yang mengalami peningkatan tiap siklusnya yang ditandai dengan lebih aktifnya mahasiswa dalam berdiskusi dalam menentukan masalah.
Relevansi masalah yang dikemukakan oleh mahasiswa pada tiap siklusnya, berangsurangsur menjadi sesuai dengan konteks materi. Dalam bertanya dan memberi komentar terlihat bahwa kemampuan inferring dan explaining pada konsep-konsep dalam IMK meningkat, sedangkan kemampuan summarizing terlihat dalam penyusunan presentasi yang dilakukan dalam tiap kelompok serta melalui kuis online dalam course IMK Besmart UNY.

Berdasarkan observasi dan wawancara kegiatan presentasi juga mengambil peranan dalam peningkatan pemahaman konsep IMK. Melalui kegiatan pemaparan hasil investigasi dan diskusi. Melalui kegiatan tersebut mahasiswa dapat bertukar pikiran dalam menyelesaikan masalahmasalah mengenai IMK yang terjadi dalam kehidupan nyata melalui kegiatan live synchronous dan collaborative asynchronous. Hal tersebut sesuai dengan penjelasan Littlejohn \& Pagler (2007, p.77) bahwa,

"during discussions, students receive feedback form tutor and/or other learners, allowing them to self assess how well they understand each concepts."

Melalui kegiatan evaluasi pada langkah analisis dan evalusi yang diterapkan pada siklus III, yaitu adanya kuis online dalam bentuk essay memberikan kemudahan mahasiswa untuk melatih diri membangun pemahaman konsepnya pada materi yang dipelajari. Aktivitas tersebut juga memberi kemudahan bagi dosen dalam mengetahui pemahaman konsep IMK yang telah dikuasi oleh mahasiswa. Hal tersebut sesuai dengan penjelasan Djemari Mardapi (2008, p.73) yaitu keunggulan bentuk soal essay dapat mengukur tingkat berfikir dari yang rendah sampai yang tinggi, mulai dari hafalan sampai evaluasi. Kuis online merupakan aktivitas dari kegiatan autonomous asynchronous.

Dengan demikian implementasi BLCA dapat meningkatkan pemahaman konsep mahasiswa Prodi TP FIP UNY dalam mata kuliah IMK. Langkah pembelajaran BLCA yang banyak berpengaruh pada peningkatan pemahaman konsep 
IMK adalah orientasi, investigasi, presentasi, dan evaluasi.

\section{Kemandirian Belajar}

Pada kondisi awal kemandirian belajar mahasiswa Prodi TP FIP UNY dalam pembelajaran IMK masih rendah yang ditunjukan dengan sikap pasif dan tidak memiliki inisiatif sendiri dalam belajar, tidak mampu melakukan kontrol diri dan otonomi dalam belajar, kurang disiplin dalam mengumpulkan tugas, serta kurang percaya diri dengan hasil belajarnya. Kemandirian belajar mahasiswa mengalami peningkatan melalui implementasi BLCA, dengan rata-rata skor angket mahasiswa pada siklus I yaitu 61,52, naik pada siklus II menjadi 64,98 , dan naik pada siklus III menjadi 68,46 .

Berdasarkan hasil angket kemandirian belajar mahasiswa baik pada siklus I, siklus II, dan siklus III telah mencapai kriteria keberhasilan pada kategori tinggi. Jumlah mahasiswa yang mencapai keman- dirian belajar dalam kategori tinggi pada siklus I yaitu $64 \%$, naik pada siklus II menjadi $78 \%$, dan naik pada siklus III menjadi $88 \%$.

Berdasarkan hasil observasi, Kemandirian belajar mahasiswa mengalami peningkatan dengan skor pada siklus I yaitu 26 (rendah), naik pada siklus II menjadi 38 (rendah), dan naik pada siklus III menjadi 36 (tinggi). Peningkatan kemandirian belajar mahasiswa dengan implementasi BLCA dari siklus I hingga siklus III, dapat disajikan pada Gambar 2.

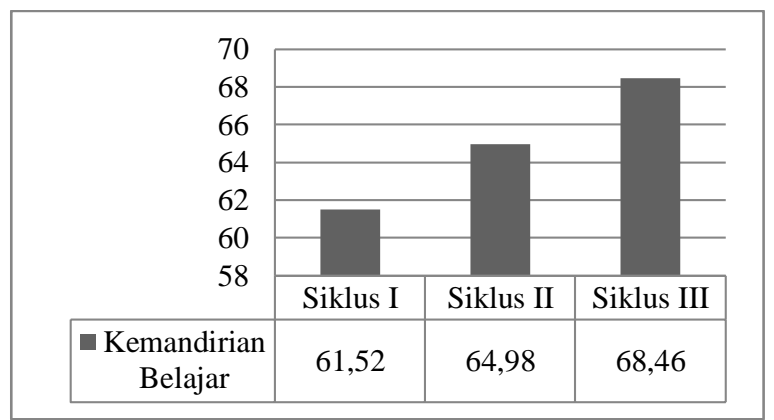

Gambar 2. Peningkatan Kemandirian Belajar Berdasarkan Angket

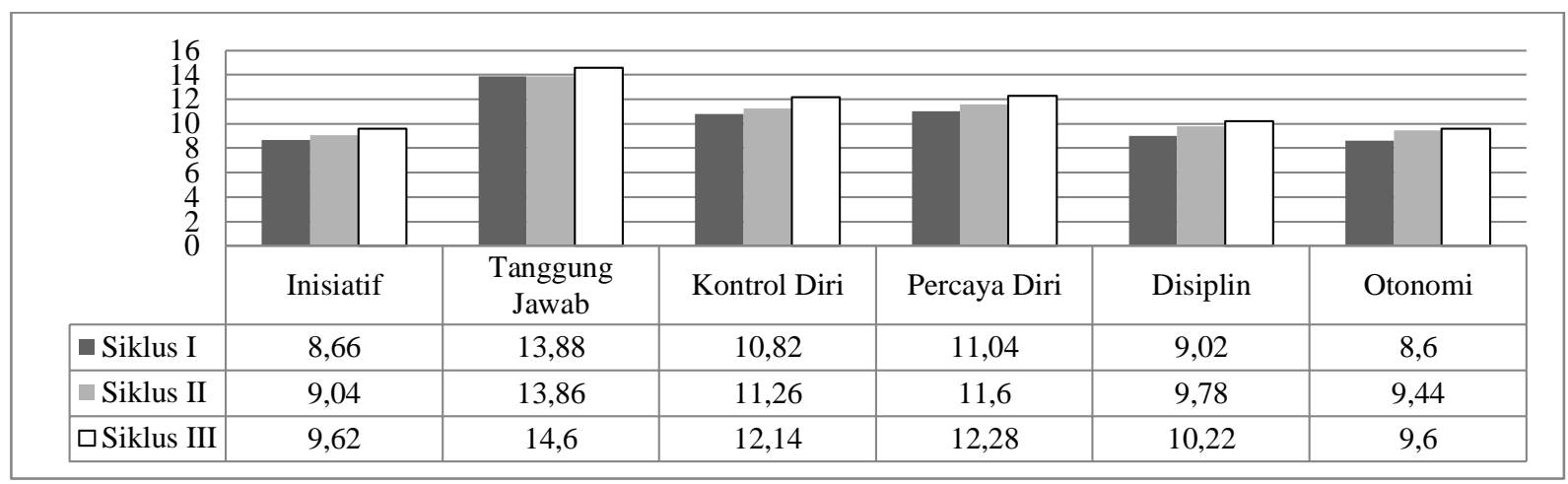

Gambar 3. Peningkatan Kemandirian Belajar Tiap Indikator

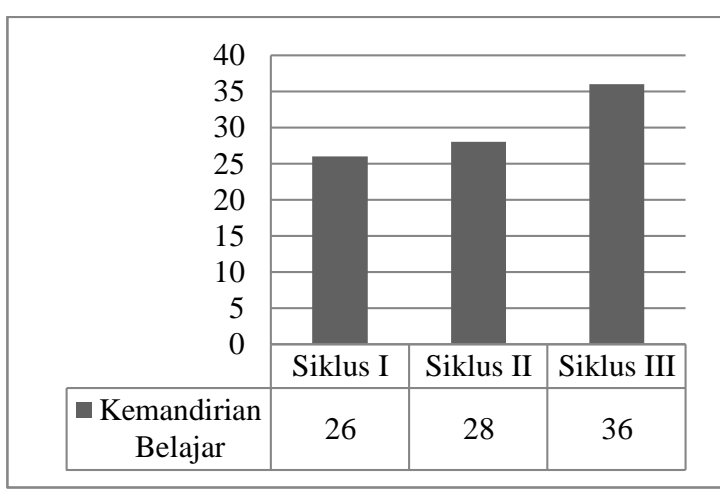

Gambar 4. Peningkatan Kemandirian Belajar Berdasarkan Observasi
Berdasarkan observasi peningkatan kemandirian belajar dari siklus I hingga siklus III terjadi karena adanya orientasi berupa motivasi dari dosen. Dosen memotivasi instrinsik mahasiswa dengan memberikan cerita dan contoh kasus implikasi materi dalam kehidupan sehari-hari, atau dengan mengaitkan urgensi materi dengan kompetensi lulusan Prodi TP yang diharapkan sehingga mahasiswa memiliki semangat dan kesadaran diri untuk belajar. Dengan adanya motivasi dalam pelaksana- 
an pembelajaran kepercayaan diri mahasiswa meningkat dalam belajar.

Dari semangat dan kesadaran diri tersebut inisiatif, tanggung jawab, kontrol diri, dan kepercayaan diri mahasiswa meningkat. Hal tersebut sesuai dengan penjelasan Gagne, et al (2005, p.114) bahwa, "motivation forces that cause a learner to engage in study behavior, focus attention on a particular learning goal, or do extra work on an assignment." Selain itu, mahasiswa yang termotivasi mempejari sesuatu dan dengan sadar merencanakan dan melakukan pembelajarannya, mempunyai kemungkinan yang lebih besar mengingat informasi yang diperoleh daripada mahasiswa lain (Slavin, 2009, p.115).

Berdasarkan hasil wawancara kegiatan organisasi, investigasi, dan presentasi mampu meningkatkan kemandirian belajar mahasiswa pada indikator insiatif, tanggung jawab, percaya diri, disiplin dan otonomi. Kegiatan organisasi dilakukan mahasiswa dengan berdiskusi pada kegiatan live synchronous. Kegiatan investigasi dilakukan secara collaborative asynchronous dan pembelajaran tatap muka secara mandiri di luar kelas. Kegiatan presentasi dilakukan secara live synchronous dan berlanjut pada collaborative asynchronous. Hal tersebut sesuai penjelas Fredericks, et al dalam Slavin (2009, p.115) bahwa, keterlibatan dan investigasi menjadikan mahasiswa terlibat dalam pembelajaran mandiri, bukan hanya melakukan pekerjaan dan mengikuti aturan.

Peningkatan kemandirian belajar mahasiswa juga terlihat dalam proses pembelajaran yang dilakukan dalam BLCA. Terbukti berdasarkan hasil observasi bahwa memberikan kebebasan kepada mahasiswa dalam menentukan kegiatan belajarnya dapat meningkatkan inisiatif, tanggung jawab, dan otonomi mahasiswa.

Kegiatan ini dilakukan dengan membebaskan mahasiswa dalam memilih sendiri topik masalah yang menarik dalam kehidupan nyata seputar materi. Selain itu, pada siklus II dan III dalam course IMK Besamart UNY terdapat link tambahan yang menghubungkan sistem tersebut dengan sumber belajar lain, sehingga mahasiswa lebih banyak memiliki otonomi dalam memilih bahan belajar yang sesuai. Dengan mencantumkan tanggal jatuh tempo pengumpulan tugas (due date) dalam course IMK Besamart UNY mahasiswa menjadi lebih peka terhadap tugas belajar yang menjadi tanggung jawabnya, sehingga kontrol diri dan kedisiplinannya meningkat.

Berdasarkan observasi dan wawancara kegiatan analisis dan evaluasi mampu meningkatkan inisiatif, kontrol diri, dan kedisiplinan mahasiswa. Dengan adanya tugas belajar yang terstruktur meliputi tugas mandiri, kelompok, dan kuis secara real-time mahasiswa dilatih untuk membiasakan diri melakukan kegiatan pembelajaran baik dalam bentuk online maupun tatap muka, sehingga kemandirian belajarnya meningkat. Dengan demikian implementasi BLCA dapat meningkatkan kemandirian belajar mahasiswa Prodi TP FIP UNY dalam mata kuliah IMK.

\section{Simpulan dan Saran}

Simpulan

Penelitian ini menghasilkan simpulan sebagai berikut. Pemahaman konsep IMK mahasiswa mengalami peningkatan melalui implementasi blended learning by the constructive approach (BLCA). Hal tersebut dilakukan dengan cara menghubungkan pengetahuan baru dengan pengetahuan yang telah dimiliki mahasiswa, menggunakan contoh konkrit, mengajarkan materi dari umum ke khusus, serta melakukan teori beriringan dengan praktek yang berbasis masalah dalam kehidupan nyata sebagai implementasi konsep IMK. Ratarata nilai tes pada siklus I yaitu 67,56 , naik pada siklus II menjadi 73,2, dan naik pada siklus III menjadi 80,9. Persentase mahasiswa yang mencapai ketuntasan belajar pada siklus I yaitu $52 \%$, naik pada siklus II menjadi $70 \%$, dan naik pada siklus III menjadi $84 \%$.

Kemandirian belajar mahasiswa mengalami peningkatan melalui implementasi blended learning by the constructive 
approach (BLCA). Hal tersebut dilakukan dengan cara memberikan penjelasan tentang kompetensi yang harus dikuasai mahasiswa Prodi TP dalam mata kuliah IMK yang dihubungkan dengan kompetensi $\mathrm{TP}$, memberikan motivasi intrinsik kepada mahasiswa mengenai keuntungan menguasai materi pada mata kuliah IMK. Peningkatan kemandirian belajar mahasiswa juga terjadi karena dosen mendemonstrasikan cara berinteraksi melalui course IMK Besmart UNY sebagai bentuk pembelajaran online.

Adanya refleksi di setiap akhir kegiatan pembelajaran serta memberikan kesempatan kepada mahasiswa untuk mengelola kegiatan belajarnya sendiri meliputi pemilihan bahan, kegiatan, dan kelompok belajar. Rata-rata skor angket pada siklus I yaitu 61,52; naik pada siklus II menjadi 64,98; dan naik pada siklus III menjadi 68,46 . Persentase mahasiswa yang mencapai keberhasilan dalam kemandirian belajar pada siklus I yaitu $64 \%$, naik pada siklus II menjadi 78\%, dan naik pada siklus III menjadi $88 \%$.

Saran

Implementasi BLCA dalam kegiatan pembelajaran membutuhkan penjelasan kegiatan pembelajaran terlebih dahulu agar dapat dimengerti oleh mahasiswa. Oleh karena itu, penjelasan tentang kegiatan pembelajaran sebaiknya diberikan di awal kegiatan belajar sehingga proses pembelajaran berjalan dengan efektif, efisien, dan mencapai tujuan pembelajaran.

BLCA memiliki beberapa komponen yang harus dikombinasikan secara fisik dan virtual yaitu ruang, waktu, media, dan aktivitas. Agar implementasi BLCA berjalan lancar, sebelumnya perlu dirancang kombinasi dari komponen-komponen tersebut secara matang.

Dosen sebaiknya lebih interaktif, demokratis, dan memberikan kebebasan yang bertanggung jawab dalam belajar kepada mahasiswa. Agar mahasiswa mampu mengeksplorasi kegiatan belajarnya se- hingga pemahaman konsep dan kemandirian belajarnya dapat meningkat.

\section{Daftar Pustaka}

Arends, Richard, I. (2008). Learning to teach. (Terjemahan Helly Prajitno Soetjipto \& Sri Mulyantini Soetjipto). New York: McGraw Hill Companies. (Buku asli diterbitkan tahun 2007).

Asri Budiningsih, C. (2005). Belajar dan pembelajaran. Jakarta: Rineka Cipta.

Association for Educational Communications and Technology (AECT). (1977). The definition of educational technology. Washington, D.C: AECT.

Bath, Debra \& Bourke, John. (2010). Getting started with blended learning. Griffith University.

Cheung, W. S., \& Hew, K. F. (2011). Desaign and evaluation of two blended learning approaches: Lessons learned. Australian Journal of Educational Technology, 8, 1319-1337.

Djemari Mardapi. (2008). Teknik penyusunan instrument tes dan nontes. Yogyakarta: Mitra Cendekia Press.

Eko Putro Widoyoko. (2012). Teknik penyusunan instrumen penelitian. Yogyakarta: Pustaka Pelajar.

Eti Nurhayati. (2011). Psikologi pendidikan inovatif. Yogyakarta: Pustaka pelajar.

FIP UNY. (2009). Buku kurikulum 2009. Yogyakarta: FIP UNY.

Gagne', Robert, M., et al. (2005). Principle of instructional design. Wadsworth: Cengage Learning.

Iskandar. (2008). Metodologi penelitian pendidikan dan sosial. Jakarta: GP Press.

Joyce, B., Weil, M., \& Calhoun, E. (2011). Models of teaching. Yogyakarta: Pustaka Pelajar.

Kemmis, S \& Robin Mc Taggart. (1990). The action research planner. Victoria: Deakin University. 
Littlejohn, Allison \& Pegler, Chris. (2007). Preparing for blended e-learning. New York: Routledge.

Nel, Elizabeth. (2005). Creating meaningful blended learning experiences in a south african higher education classroom: An action inquiry. Bloemfontein: University of the Free State.

Seels, Barbara B., \& Richey, Rita C. (1994). Teknologi pembelajaran definisi dan kawasannya. Jakarta: AECT/UNJ.

Slavin, Robert, E. (2012). Educational psycology. Boston: Pearson.

Sugiyono. (2012). Statistik untuk penelitian. Bandung: Alfabeta.

Trianto. (2011). Mendesain model pembelajaran inovatif progresif. Jakarta: Kencana.
UNY. (2011). Peraturan akademik universitas negeri yoyakarta. Yogyakarta: UNY.

Uwes A. Chaeruman. (2011). Implementing blended learning: a case based sharing experience. Diambil pada tanggal 30 November 2012 pukul 16.35 dari http://www.teknologipendidikan. net/2011/06/21/implementingblended-learning-a-case-basedsharing-experience/

Wijaya Kusumah, \& Dedi Dwitagama. (2010). Mengenal penelitian tindakan kelas. Jakarta: PT. Indeks.

Yusufhadi Miarso. (2007). Menyemai benih teknologi pendidikan. Jakarta: Kencana. 